\title{
Removal of Antibiotics and Nutrients by Vetiver Grass (Chrysopogon zizanioides) from a Plug Flow Reactor Based Constructed Wetland Model
}

\author{
Saumik Panja ${ }^{1}\left(\mathbb{D}\right.$, Dibyendu Sarkar ${ }^{1, *} \mathbb{D}$, Zhiming Zhang $^{1}$ and Rupali Datta ${ }^{2} \mathbb{D}$ \\ 1 Department of Civil, Environmental and Ocean Engineering, Stevens Institute of Technology, \\ Hoboken, NJ 07030, USA; saumikpanja@gmail.com (S.P.); zzhan100@stevens.edu (Z.Z.) \\ 2 Department of Biological Sciences, Michigan Technological University, Houghton, MI 49931, USA; \\ rupdatta@mtu.edu \\ * Correspondence: dsarkar@stevens.edu
}

Citation: Panja, S.; Sarkar, D.; Zhang, Z.; Datta, R. Removal of Antibiotics and Nutrients by Vetiver Grass (Chrysopogon zizanioides) from a Plug Flow Reactor Based Constructed Wetland Model. Toxics 2021, 9, 84 . https://doi.org/10.3390/toxics 9040084

Academic Editor: Conceptión Calvo

Received: 10 March 2021

Accepted: 13 April 2021

Published: 15 April 2021

Publisher's Note: MDPI stays neutral with regard to jurisdictional claims in published maps and institutional affiliations.

Copyright: (c) 2021 by the authors. Licensee MDPI, Basel, Switzerland. This article is an open access article distributed under the terms and conditions of the Creative Commons Attribution (CC BY) license (https:// creativecommons.org/licenses/by/ $4.0 /)$.

\begin{abstract}
Overuse of antibiotics has resulted in widespread contamination of the environment and triggered antibiotic resistance in pathogenic bacteria. Conventional wastewater treatment plants (WWTPs) are not equipped to remove antibiotics. Effluents from WWTPs are usually the primary source of antibiotics in aquatic environments. There is an urgent need for cost-effective, environment-friendly technologies to address this issue. Along with antibiotics, nutrients (nitrogen and phosphorus) are also present in conventional WWTP effluents at high concentrations, causing environmental problems like eutrophication. In this study, we tested vetiver grass in a plug flow reactor-based constructed wetland model in a greenhouse setup for removing antibiotics ciprofloxacin (CIP) and tetracycline (TTC), and nutrients, N and P, from secondary wastewater effluent. The constructed wetland was designed based on a previous batch reaction kinetics study and reached a steady-state in 7 days. The measured concentrations of antibiotics were generally consistent with the modeling predictions using first-order reaction kinetics. Vetiver grass significantly $(p<0.05)$ removed $93 \%$ and $97 \%$ of CIP and TTC (initial concentrations of $10 \mathrm{mg} / \mathrm{L}$ ), simultaneously with $93 \%$ and $84 \%$ nitrogen and phosphorus, respectively. Results show that using vetiver grass in constructed wetlands could be a viable green technology for the removal of antibiotics and nutrients from wastewater.
\end{abstract}

Keywords: vetiver grass; phytoremediation; constructed wetland; antibiotics; nutrients

\section{Introduction}

Pharmaceutical compounds are major emerging contaminants that persist in soil and aquatic environments due to their prolonged bioactivity [1]. Antibiotics in the environment are considered a major concern since they trigger antimicrobial resistance in bacteria and impact the ecosystem in various ways. Recently, the European Union and the United States conducted a nationwide surface water sampling study which revealed the existence of several antibiotics, such as macrolides and quinolones, in aquatic ecosystems [2]. Most of the antibiotics are highly polar and have low volatility which is optimal for activity in the human physiological system. A few lipophilic varieties of antibiotics also exist which facilitates their trophic transfer in aquatic ecosystems [3,4]. Among all the synthetic antibiotics, fluoroquinolones have a significant market share as they are widely prescribed by physicians. Ciprofloxacin (CIP) is one of the major fluoroquinolone antibiotics that is used in human health care and veterinary practices. Tetracycline (TTC) is a naturally sourced antibiotic that is obtained from Streptomyces sp. and used to treat diseases such as malaria, rosacea, chlamydia, etc. [5-7]. TTC is also administered to animals as a growth promoter in concentrated animal feeding operations. Both CIP and TTC are non-volatile solids and contain acidic and basic functional groups. Depending on the $\mathrm{pH}$, they can exist as anions, cations, or zwitterions in the aqueous phase. Their solubility and octanol-water distribution ratio also depend on the solution $\mathrm{pH}$ [8-10]. 
Due to the alarming increase of pharmaceutical compounds, personal care products, and endocrine disruptors in the environment, many nations are considering different countermeasures and implementing regulatory actions to control their negative environmental impact. Wastewater treatment plants (WWTPs) that receive effluents from pharmaceutical industries and hospitals serve as major contributors to these emerging contaminants in the aquatic environment. Conventional WWTPs not only release antibiotics through their effluents but also serve as point sources for nutrient (e.g., nitrogen and phosphorus) discharge, causing environmental problems like eutrophication. Constant nutrient loadings into surface water pose an increasing threat to the aquatic ecosystem [11,12]. Increasing urbanization has also resulted in increased nitrate leaching into groundwater, which constitutes a major ecological and human health risk [13]. Other drawbacks of conventional WWTPs include a significant consumption of energy (e.g., activated sludge processes for the removal of organics) and the disposal of the residual sludge, which impose a financial burden on the operation and management (O\&M) cost [14-16]. Some physicochemical processes, including advanced oxidation via ozonation [17] or ferrous-activated persulfate [18], photodegradation [19], and adsorption [20,21], have been tested for antibiotics removal, but these treatments are cost-intensive and may generate toxic derivatives from the parent antibiotic compounds.

In contrast, the application of phytoremediation for contaminant removal has become popular due to its ability to remove a diverse range of organic and inorganic contaminants from soil and water with a variety of advantages, such as low O\&M cost, simple design, and low or no environmental impacts [4,22-28]. Phytoremediation comprises a series of unique processes such as absorption, adsorption, degradation, and biotransformation of contaminants [29-32]. Not only do the plants decontaminate pollutants but also the exudates released from plant root systems catalyze microbial growth and facilitate exocellular biotransformation of organic contaminants.

The ideal candidates for phytoremediation are macrophytes that can tolerate, and accumulate/degrade, toxic pollutants in their tissues. Vetiver grass (Chrysopogon zizanioides) is one of the best-suited species for nutrient removal [33,34]. Being a member of the grass family, vetiver is a fast-growing, high biomass tropical perennial grass that has a massive root system. Vetiver grass was also reported to withstand extreme conditions like acidic environment $(\mathrm{pH}=0.6)$, concentrated nutrients (nitrate concentrations up to $350,000 \mathrm{mg} / \mathrm{L}$ ), freezing temperature $\left(5^{\circ} \mathrm{F}\right.$ or $\left.-15^{\circ} \mathrm{C}\right)$, and drought (up to 15 months) $[33,34]$. The multipurpose applications of vetiver grass include prevention of soil erosion $[35,36]$, protection of river banks [37-39], removal of lead from soil [40-43], management of acid mine drainage impacted soil and water [44-46], removal of explosives from soil and water [44,47-50], decontamination of heavy metals from landfill leachate [51,52], removal of antibiotics from soil and water [53-55], and removal of nutrients (nitrogen and phosphorus) [56], etc. Our previous batch studies have shown that vetiver grass is not only capable of removing antibiotics (TTC and CIP) from wastewater but also degrading and metabolizing antibiotic molecules [54,57-59].

Plug flow treatment is an efficient technology used where space is a prime concern. The residence time can be efficiently manipulated in a plug flow reactor (PFR) to achieve contaminant removal. Constructed wetlands, as a sustainable and cost-effective technology, exhibit great potential to treat domestic, agricultural, and industrial wastewater. However, phytoremediation treatment processes for emerging contaminants (e.g., antibiotics) via vegetated constructed wetland are often considered as a 'black box' due to the lack of proper scientific investigation [60]. Thus, the major objective of this study was to investigate the efficiency of a vegetated (using vetiver grass) constructed wetland in the form of a PFR to remove CIP and TTC from secondary wastewater effluent. In addition to antibiotics, our objectives were to characterize the removal of nutrients (i.e., nitrogen and phosphorous) and carbon using the PFR. 


\section{Materials and Methods}

\subsection{Reagents}

Reagent grade ( $\geq 98 \%$ ) CIP and TTC were procured from Sigma Aldrich (MilliporeSigma, St. Louis, MO, USA). Trace metal grade ortho-phosphoric acid $\left(\mathrm{H}_{3} \mathrm{PO}_{4}, \mathrm{CAS}\right.$ 7664-38-2), HPLC grade methanol (CAS 67-56-1), and acetonitrile (CAS 75-05-8) were purchased from Fisher Scientific (Fairlawn, NJ, USA). Anhydrous oxalic acid $\left(\mathrm{C}_{2} \mathrm{H}_{2} \mathrm{O}_{4}\right.$, CAS 144-62-7) was purchased from Acros Organics (Fairlawn, NJ, USA).

\subsection{Wastewater Collection}

The secondary treatment run-off effluent was collected from the secondary clarifier at Joint Meeting Wastewater Treatment Plant (Capacity: 85 million gals or 322 million L per day) located at Elizabeth, NJ, USA. The plant serves the urban areas of two majorly populated counties (Essex and Union) in NJ, USA. Approximately $2300 \mathrm{~L}$ of wastewater were collected in 32-gallon polyethylene containers. The wastewater effluent was transported immediately to the laboratory and stored in $4{ }^{\circ} \mathrm{C}$. Primary characterization for wastewater was performed on the same day of collection.

\subsection{Experimental Design}

Vetiver slips (8-10 inches long), supplied by Agriflora Tropicals in Puerto Rico, were initially potted in a greenhouse environment $\left(25^{\circ} \mathrm{C}\right.$ and $14 \mathrm{~h}$ photoperiod $)$ using a commercially available potting mixture for two months. Then, the plants were taken out of the pots and the roots were thoroughly washed to remove soil particles. Roots and shoots were trimmed using a sterilized pruning tool, and the roots were submerged into $0.5 \times$ Hoagland's solution for acclimatization (for 20 days) in a Thermo Scientific Precision plant growth chamber.

\subsection{Constructed Wetland Setup}

Two 150-gallon $\left(0.57 \mathrm{~m}^{3}\right)$ tanks were used for setting up a mesocosm scale constructed wetland. Acrylic sheet baffles (1/8 inch or $0.32 \mathrm{~cm}$ in width) were used to make partitions in the tank (Figure 1). The inner dimension of the tank was measured to design 3 baffles that can fit edge to edge inside the tank. Then, the acrylic sheets were cut accordingly in a machine shop. Some extra portions were also cut to maintain the cross-sectional area of the PFR (Figure 1). The baffles were inserted and sealed with non-toxic inert silicone-based aquarium glue so that water can only pass through the cross-sectional area. Water inlet and outlet (Figure 1) were installed in each tank using lead-free quick-connect straight valves (1/4-inch or $0.64 \mathrm{~cm}$ OD). PVC clear vinyl tubing (1/4-inch or $0.64 \mathrm{~cm}$ OD) was used for supplying water from the storage tank to the wetland. A two-channel Ismatec peristaltic pump (ISM 832, Cole-Parmer, IL, USA) was used to pump the wastewater from the storage to the wetland tank. Customized floating beds manufactured from inert materials were purchased from Floating Islands West LLC (Mokelumne Hill, CA, USA) and used to setup the vegetated macrophyte bed in the wetland tank. The beds were modified by cutting holes small enough to insert the plant roots through them. Plants (Figure 2A) were weighed ( $4 \%$ of the volume) and equally distributed in the floating bed panels. The control tank contained only the baffles and floating beds (Figure $2 \mathrm{C}$ ). The overall reaction was assumed in PFR mode owing to the evenly distributed vetiver plants in the system that are expected to have similar reactions with chemicals along the water path. The feasibility of this PFR model was assessed by comparing it with experimental data for CIP and TTC removal. The hydraulic retention time (HRT) was determined $(\theta=7$ days) using the first-order reaction kinetics from previous batch studies [57]. The wastewater flow rate was set to $50 \mathrm{~mL} / \mathrm{min}$ and the hydraulic loading rate (HLR) was maintained at $34 \mathrm{~mL} / \mathrm{m}^{2}$-min. The elevation of the tank was adjusted in a way to approximately match the flow rate of inflow and outflow of the water. Several dry runs were performed using tap water to optimize the physical parameters before starting the actual experiment. Concentrated stock solutions of CIP and 
TTC were added $(10 \mathrm{mg} / \mathrm{L})$ in the feed tank and stirred overnight to dissolve. The initial concentrations of both antibiotics were checked using HPLC.

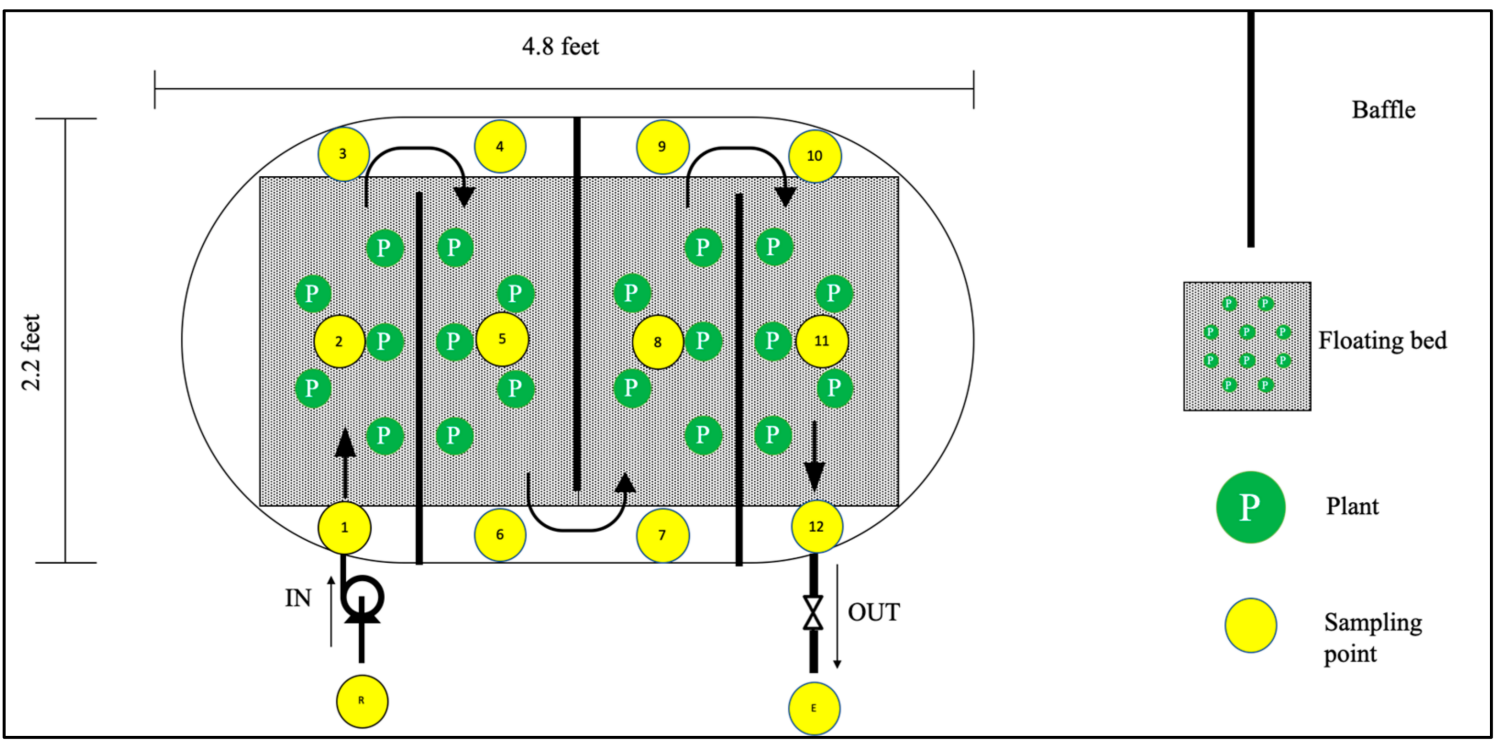

Figure 1. Schematic diagram of the constructed wetland.
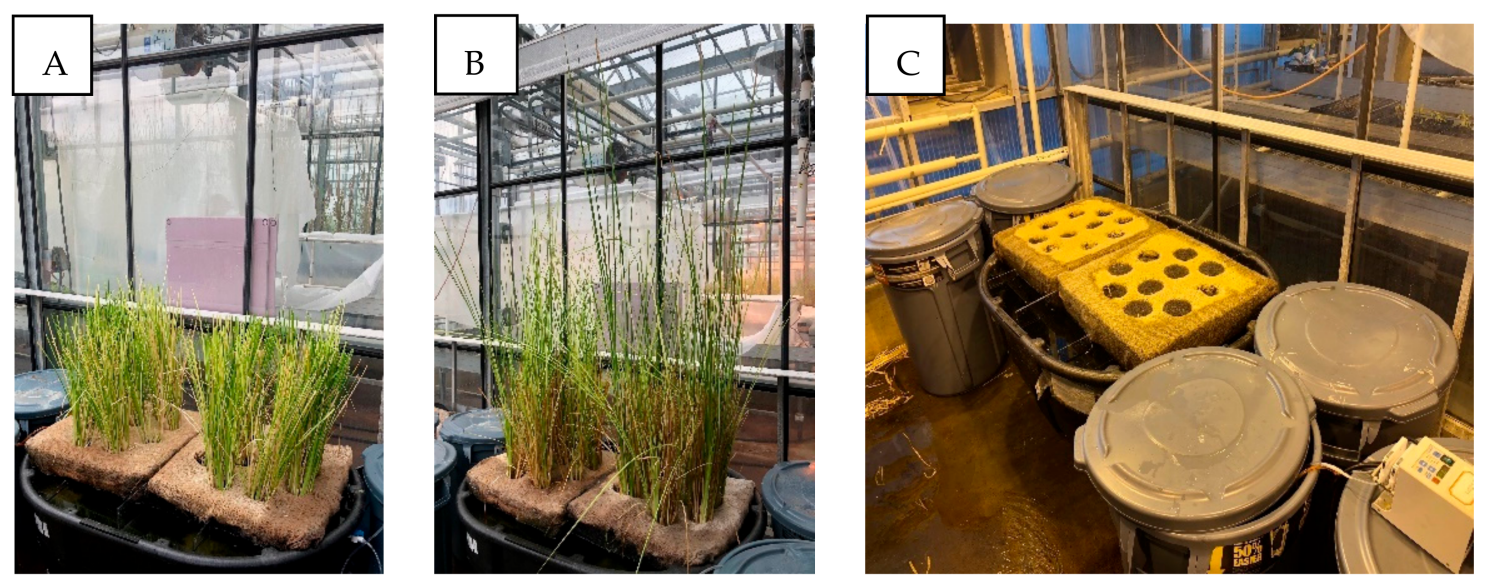

Figure 2. The vegetated (A,B) and plant-free control (C) plug flow reactor (PFR)-based constructed wetland system. Vetiver grass before the start of the experiment (A) and the growth of grass after 15 days (B).

\subsection{Analytical Methods}

\subsubsection{Physico-Chemical Parameters}

Physico-chemical parameters like temperature, $\mathrm{pH}$, and electrical conductivity were measured using a multi-parameter water quality sonde (YSI-6820, YSI, OH, USA). The pH meter was calibrated each time using standard solutions before sample measurement.

\subsubsection{Chlorophyll Content}

Chlorophyll (Chl) content of the plant leaves was determined according to Liu et al. (2013) [61]. In brief, fresh plant leaves were homogenized in $5 \mathrm{~mL}$ of $80 \%(v / v)$ aqueous acetone followed by filtration. Then, the absorbance (663 and $645 \mathrm{~nm}$ ) of the filtrate was measured using Citation 3, Biotek ${ }^{\circledR}$ microplate reader. The following equations were used to determine $\mathrm{Chl} \mathrm{A}$ and $\mathrm{Chl} \mathrm{B}$ content, respectively [62].

$$
\text { Chl } A=0.00127 A b s_{663}-0.00269 A b s_{645}
$$




$$
\text { Chl } B=0.0229 A b_{645}-0.00468 A b s_{663}
$$

\subsubsection{Antibiotics}

Antibiotic content in the wastewater were analyzed according to Panja et al. (2020) [57]. Briefly, CIP and TTC content in samples were analyzed using Agilent 1260 HPLC system (Agilent, CA, USA) equipped with a photodiode array (PDA) detector and a 1260 series autosampler. For both antibiotics, a Hypersil gold C18 column $(150 \times 4.6 \mathrm{~mm}, 5 \mu \mathrm{m})($ Thermo Scientific, MA, USA) with a corresponding Hypersil gold guard column $(10 \times 4 \mathrm{~mm}, 5 \mu \mathrm{m})$ were used. The acidic $(\mathrm{pH}=3)$ mobile phase used for CIP detection contained orthophosphoric acid and acetonitrile $(80: 20 \mathrm{v} / \mathrm{v})$. The wavelength of the UV detector was set at $360 \mathrm{~nm}$. The mobile phase for TTC samples elution contained $0.01 \mathrm{M}$ oxalic acid: acetonitrile: methanol (150:20:20 by volume). The flowrate for both TTC and CIP analysis was maintained at $1.5 \mathrm{~mL} / \mathrm{min}$ and the sample injection volume was set at $25 \mu \mathrm{L}$. The HPLC was calibrated using standard solutions of CIP and TTC. Method detection limits for CIP and TTC were $10 \mathrm{ug} / \mathrm{L}$ and $0.1 \mathrm{mg} / \mathrm{L}$, respectively.

\subsubsection{Total Nitrogen, Total Phosphorus, and Chemical Oxygen Demand}

Total nitrogen (TN), total phosphorus (TP), and chemical oxygen demand (COD) of all samples were measured using Hach test kits (Hach, CO, USA). A Hach 36 chamber digestion block was used to digest water samples for the determination of COD. A DR 6000 UV Vis spectrophotometer (Hach, CO, USA) was used for all the analyses. Detection limits for TN and TP were $0.1 \mathrm{mg} / \mathrm{L}$ and $0.06 \mathrm{mg} / \mathrm{L}$, respectively.

\subsubsection{Statistical Analysis}

JMP Pro 11 (SAS Inc., Cary, NC, USA) was used for all statistical analyses. Q-tests were performed on all data to eliminate possible outliers at the $95 \%$ confidence interval. All samples from each treatment were taken in triplicates. Tukey Kramer HSD test was done to determine significant differences among treatment means.

\section{Results}

\subsection{Wastewater Characterization}

The physical and chemical analysis of the wastewater revealed that both nitrogen and phosphorous were present as primary pollutants at concentrations of 14.4 and $12.3 \mathrm{mg} / \mathrm{L}$, respectively (Table 1). The water was mildly turbid upon collection 13.4 NTU (Nephelometric Turbidity Units). The activated sludge treatment process removes most of the organic load from wastewater. The secondary wastewater effluent contained $62 \mathrm{mg} / \mathrm{L}$ chemical oxygen demand (COD) and $21 \mathrm{mg} / \mathrm{L}$ total organic carbon (TOC). The $\mathrm{pH}$ of the collected wastewater was neutral at 6.8 and the electrical conductivity was $801 \mu \mathrm{S} / \mathrm{cm}$.

Table 1. Physical and chemical characteristics of secondary wastewater effluent.

\begin{tabular}{ccc}
\hline Wastewater Parameters & Values & Units \\
\hline $\mathrm{pH}$ & 6.8 & \\
Electrical conductivity & 801 & $\mathrm{\mu S} / \mathrm{cm}$ \\
Turbidity & 13.4 & $\mathrm{NTU}$ * \\
Dissolved oxygen & 7.3 & $\mathrm{mg} / \mathrm{L}$ \\
Chemical oxygen demand (COD) & 62 & $\mathrm{mg} / \mathrm{L}$ \\
Total nitrogen (TN) & 14.4 & $\mathrm{mg} / \mathrm{L}$ \\
Total phosphate (TP) & 12.3 & $\mathrm{mg} / \mathrm{L}$ \\
Total organic carbon (TOC) & 21 & $\mathrm{mg} / \mathrm{L}$ \\
\hline
\end{tabular}

NTU, Nephelometric Turbidity Units.

\subsection{Constructed Wetland Experiment}

Our previous studies have demonstrated rapid removal of antibiotics CIP and TTC during the first 5-7 days of the treatment [57]. We determined that the initial drop in the 
antibiotic concentration followed first-order reaction kinetics (reaction kinetic constant $\mathrm{k}=0.16$ day $^{-1}$ ) [58]. Depending on this kinetic constant, we modulated the flow of influent so that the HRT of the reactor remained at 7 days. As per our model prediction, the reactor was estimated to enter a steady-state condition by day 7 , which was demonstrated by a preliminary simulation experiment and the relatively steady concentrations of antibiotics, nutrients, and COD in the effluent on and after day 7 in this study (Figures 3-6). By installing the baffles, we elongated the influent path length to $3.05 \mathrm{~m}$ (Figure 1). Vetiver grass showed extensive growth (both root and shoot) in the wastewater-fed hydroponic setup (Figures 2B and 7).
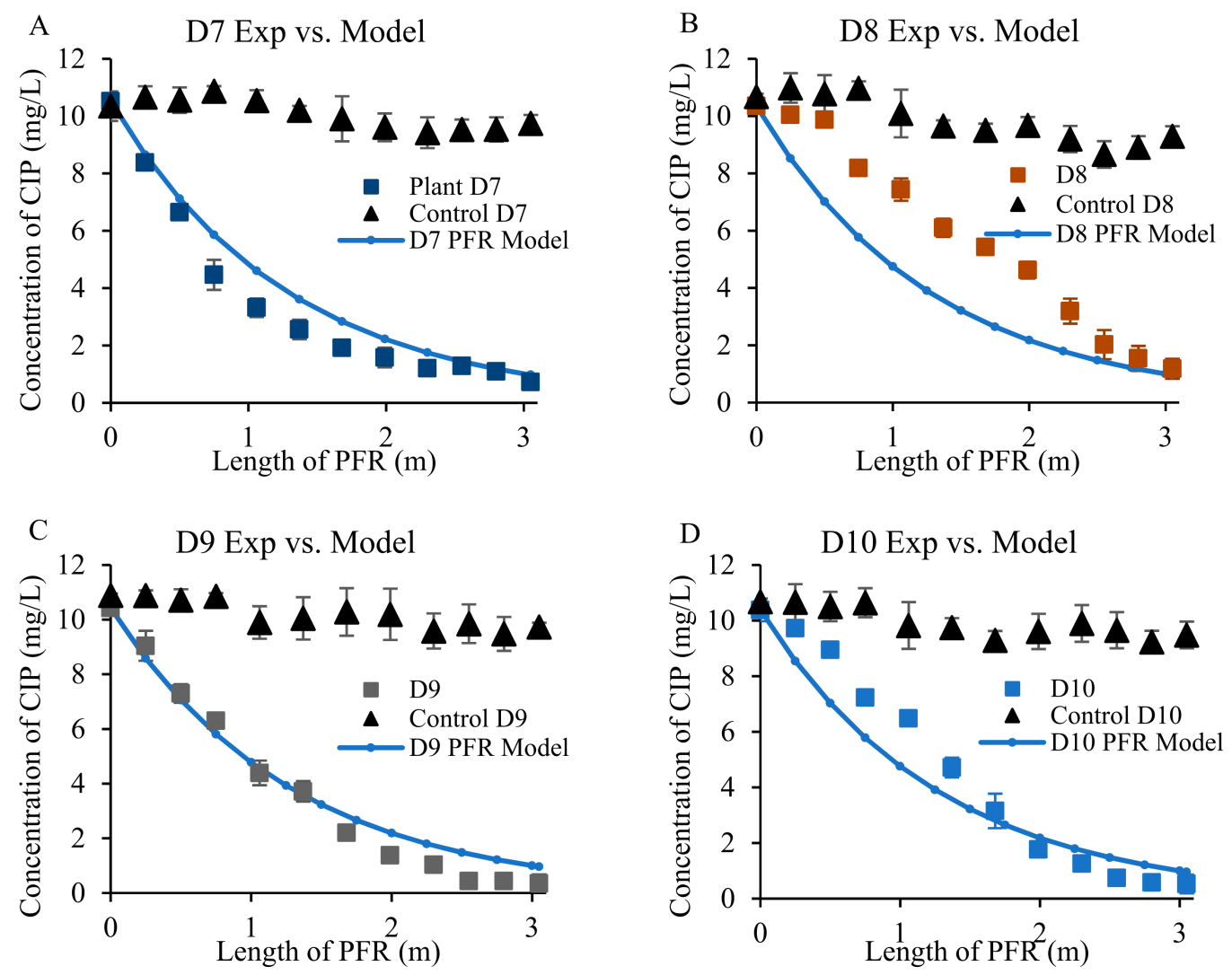

Figure 3. Removal of ciprofloxacin (CIP) according to predicted and experimental data for day 7 (D7, A), Day 8 (D8, B), Day 9 (D9, C), and Day 10 (D10, D).
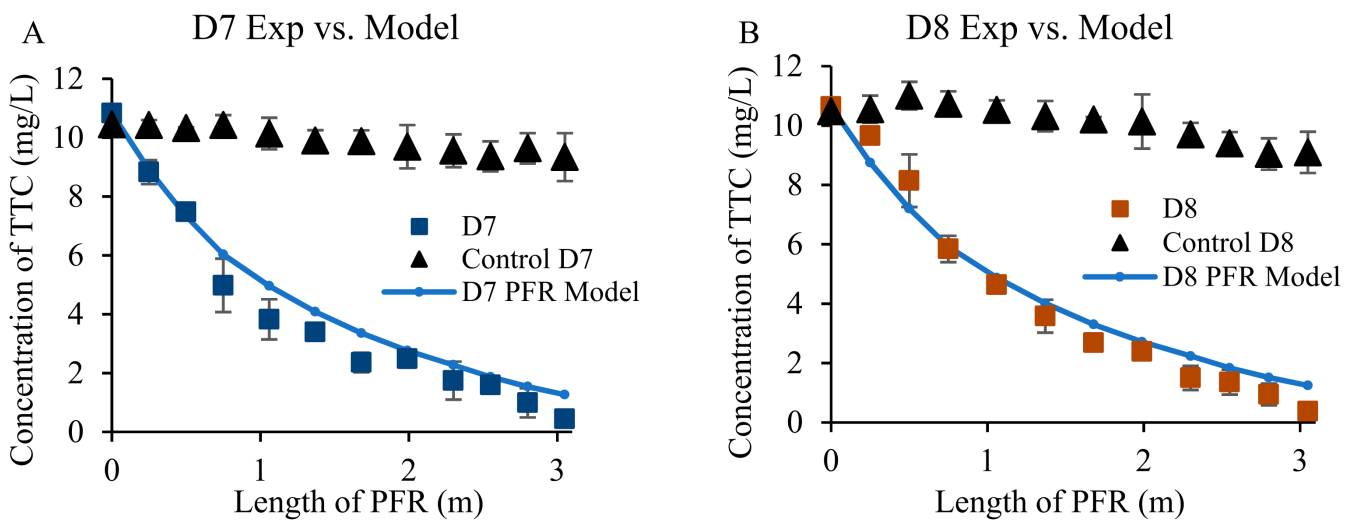

Figure 4. Cont. 

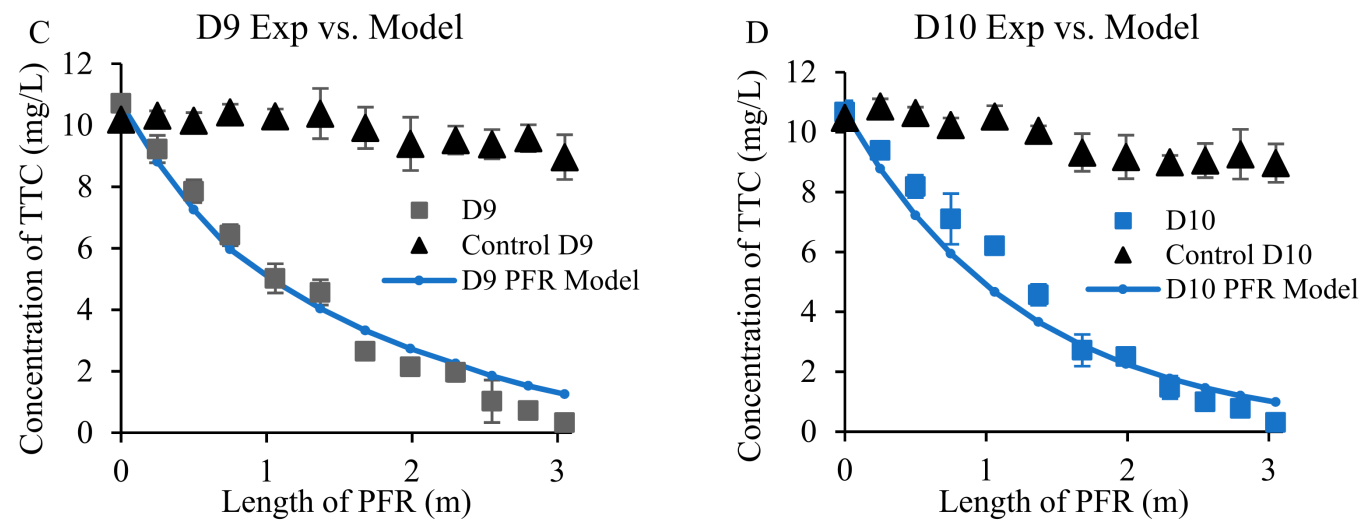

Figure 4. Removal of tetracycline (TTC) according to predicted and experimental data for day 7 (D7, A), Day 8 (D8, B), Day 9 (D9, C), and Day 10 (D10, D).
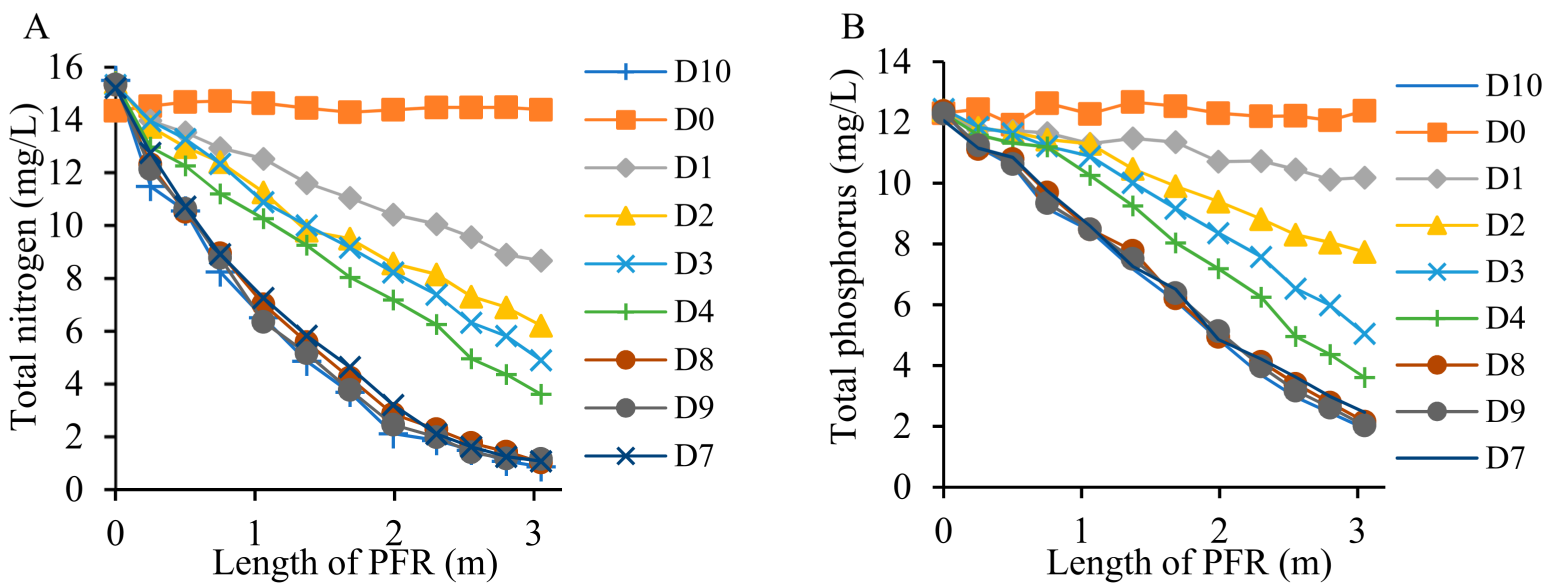

Figure 5. Removal of total nitrogen (TN) (A) and total phosphorus (TP) (B) in pre- and post- steady-state conditions from vegetated constructed wetland (D0-D10).

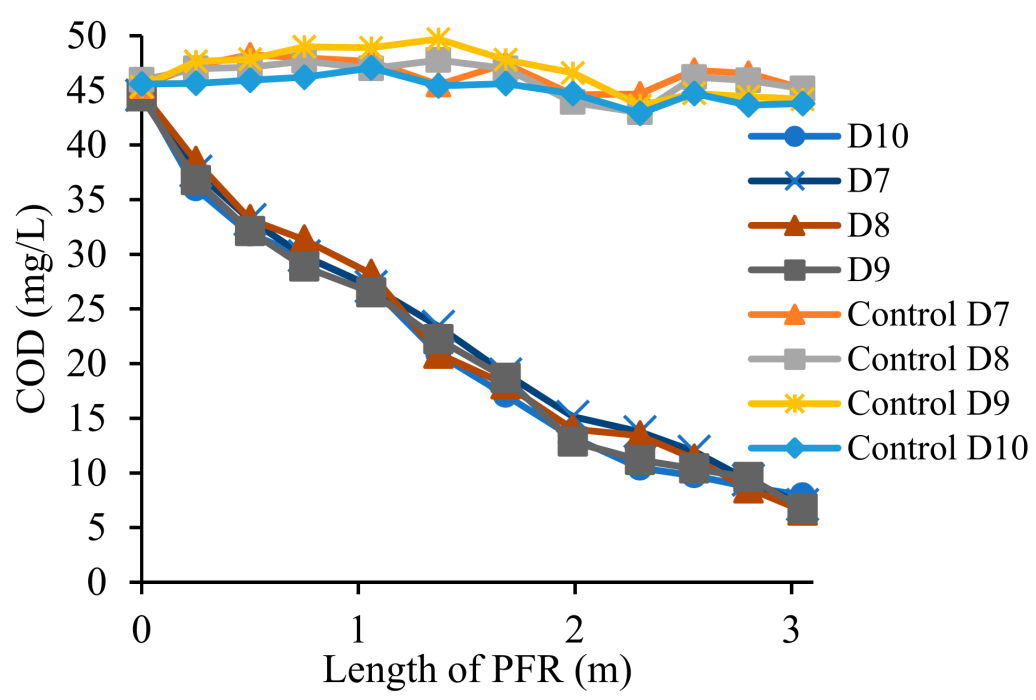

Figure 6. Removal of chemical oxygen demand (COD) in steady-state condition from both vegetated and plant-free constructed wetland (D7-D10). 

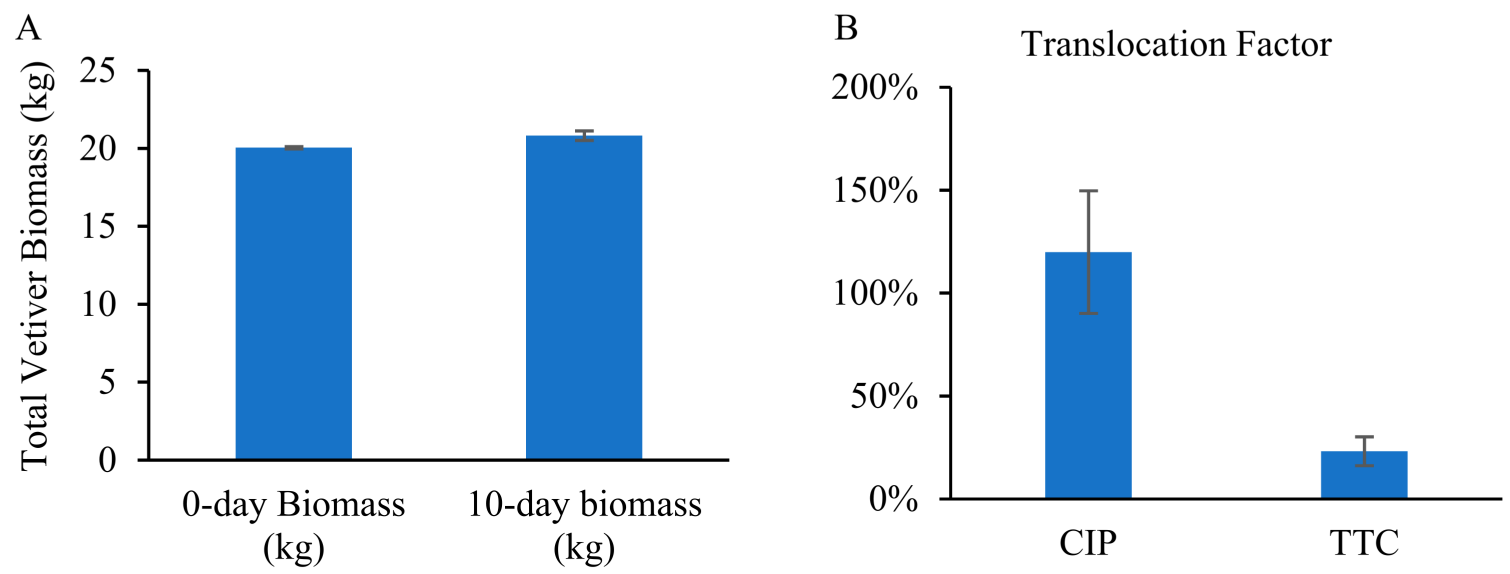

Figure 7. Comparison of initial and final total biomass of vetiver grass during the experimental period (A) and root to shoot translocation factor of CIP and TTC (B).

\subsection{Removal of Antibiotics from Wastewater}

The constructed wetland reached a steady-state after 7 days, confirmed by the relatively stable concentrations of antibiotics, nutrients, and COD in the effluent. During the steady-state condition, the difference between influent and effluent in terms of antibiotic (CIP and TTC) concentrations was statistically significant $(p<0.05)$. On average, vetiver grass removed $93 \%$ and $97 \%$ of the initial CIP and TTC content $(10 \mathrm{mg} / \mathrm{L}$ each), respectively, across the length of the PFR (Figures 3 and 4).

A simulation of CIP and TTC distributions using the ideal PFR model was compared with experimental measurements to illustrate the reaction status in the constructed wetland. The simulated concentration at each sampling port is calculated by Equation (3):

$$
C_{\text {model }}=C_{0} \times e^{-k t}
$$

where $C_{\text {model }}(\mathrm{mg} / \mathrm{L})$ is the simulated concentration for CIP or TTC, $C_{0}(\mathrm{mg} / \mathrm{L})$ is the concentration of CIP or TTC in the influent (i.e., $10 \mathrm{mg} / \mathrm{L}$ for both), $k\left(\right.$ day $\left.^{-1}\right)$ is the reaction kinetic constant 0.16 day $^{-1}$, and $t$ (day) is the absolute residence time for each sampling port.

Results showed that there was a general match between the experimental and predictive model data points (Figures 3 and 4), except for only one CIP data set obtained on day 8 (Figure 3B) which showed an average of $20 \%$ deviation between simulated and experimental values. The overall PFR simulation for TTC removal was better than that of CIP. This may be caused by the difference in the vetiver's tolerance to the two antibiotics. The deviation of experimental data from the predicted value on day 8 could be related to plant stress to CIP. Ideally, the plant-free control reactor was optimized to reach a steady-state within a week, which was similar to the vegetated constructed wetland. The equality of variance was tested between control and treatment. For each day in a steady-state condition (Day 7 to Day 10, indicated as D7-D10), the variance between control and treatment was not equal for all comparisons at a 99\% confidence level. Welch's two-sample t-test, which was performed to test the difference in mean between control and treatment, revealed that the two populations (unplanted control and vetiver treatment) means were also unequal at a $1 \%$ level of significance. In the plant-free control setup, the CIP and TTC concentrations dropped by $11 \%$ and $15 \%$, respectively, during steady-state.

\subsection{Removal of Nutrients from Wastewater}

Figure 5 shows that the concentrations of both TN and TP in the effluent dropped gradually from day 0 to day 7 . The reactor reached a steady-state condition on day 7 , as those concentrations in each sampling port as well as in the effluent remained stable after that time. Similar to antibiotics removal, vetiver significantly $(p<0.05)$ removed TN and 
TP from the PFR-based constructed wetland. In steady-state conditions, $93 \%$ of TN and $84 \%$ of TP were depleted from secondary wastewater effluent (Figure 5). Figures S1 and S2 show the removal of TN and TP in comparison to our model prediction. As seen in the case of antibiotics, there was a good match between the experimental and predictive model data points.

\subsection{Removal of COD from Wastewater}

As the antibiotic content contributes toward organic carbon, the COD of the antibiotic spiked wastewater was approximately $10 \%$ greater than the actual raw secondary wastewater effluent. Vetiver grass successfully consumed $84 \%$ of total COD from the wastewater during steady-state, along with the removal of antibiotics and nutrients. During steadystate (D7-D10), there were no significant $(p<0.05)$ differences in the data points obtained from both the vegetated constructed wetland and the plant-free control (Figure 6). The negligible COD decline (up to $4 \%$ ) in the plant-free control PFR may be attributed to the growth of antibiotic-resistant organisms.

\subsection{Chlorophyll Content and Biomass Development}

Figure 8 shows the contents of $\mathrm{Chl} \mathrm{A}, \mathrm{Chl} \mathrm{B}$, and total $\mathrm{Chl}$ in vetiver grass. Chl A content increased by $3 \%$ by the end of the 10-day experimental period and Chl B content remained the same. We did not observe any significant $(p<0.05)$ difference in the chlorophyll content before and after the experimental period.
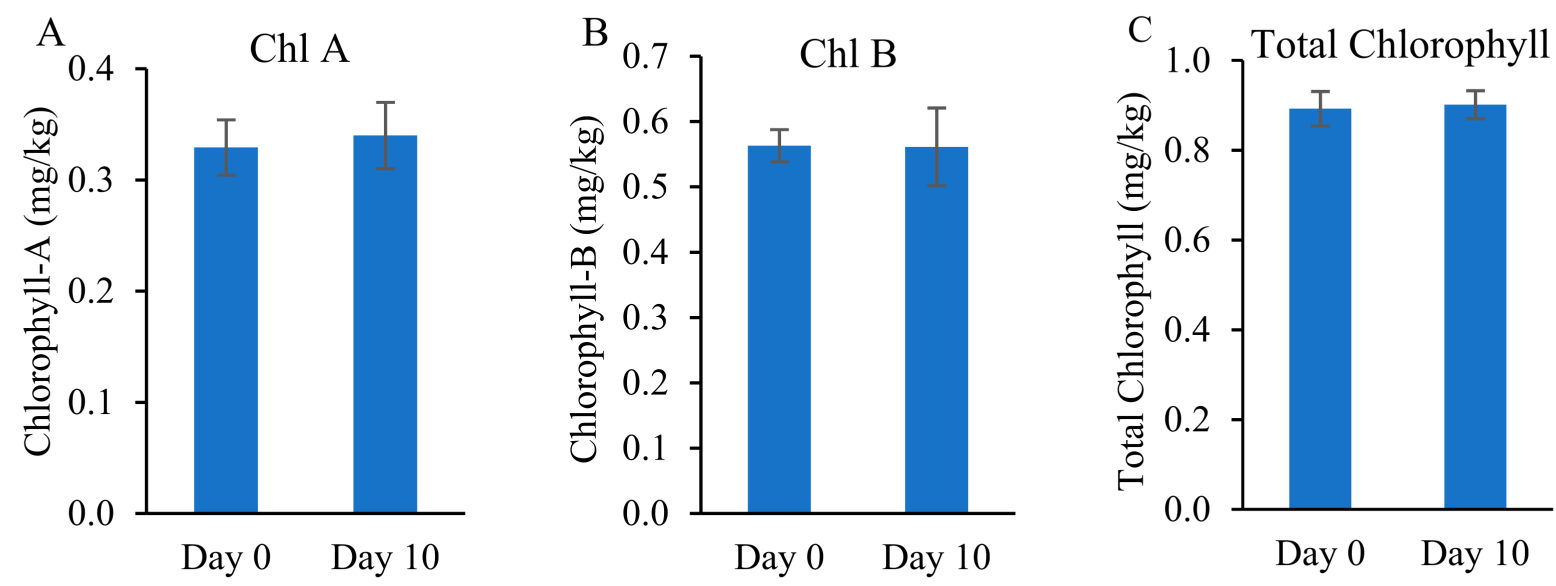

Figure 8. Comparison of the initial and final content of chlorophyll-A (A), chlorophyll-B (B), and total chlorophyll (C) in vetiver grass.

\section{Discussion}

The results obtained in this study show that vetiver grass in a constructed wetland setup was able to remove antibiotics and nutrients with high efficiency. The removal kinetics of these contaminants followed the PFR model predictions and reached a steadystate after 7 days. This result is similar to our previous studies, where we observed biphasic antibiotics (CIP and TTC) removal by vetiver grass [57]. The rapid uptake of antibiotics up to 5-7 days was followed by a slower removal subsequently [57]. We determined that the initial drop in the antibiotic concentration followed first-order reaction kinetics (reaction kinetic constant $\mathrm{k}=0.16$ day $^{-1}$ ) [58].

Previous literature reported that the removal of CIP and TTC was mainly through adsorption by plant roots, and translocation from roots to shoots may be limited [63,64]. The massive root system of vetiver grass contributed to the high removal efficiencies in both CIP and TTC. The removal trend for CIP and TTC is consistent with our previous studies that vetiver grass showed more affinity towards the removal of TTC compared to the CIP $[57,58]$. This difference could be due to the difference in how CIP and TTC impact the 
vetiver, causing variation in uptake and accumulation of these antibiotics $[54,59,63]$. The overall performance of vetiver grass in a PFR-based constructed wetland system was better than in our previous batch study. Specifically, our previous hydroponic batch experiments showed vetiver grass removed only $71 \%$ of CIP and $90 \%$ of TTC after 7 days [56]. The flow condition in a PFR system promotes better contact of the antibiotics with vetiver roots, thus facilitating improved removal compared to batch reactions. Another reason for improved antibiotic removal could be the cumulative/bulk effect.

The vetiver plants showed good growth and survived well until the end of the experiment, although a few common stress symptoms (e.g., mild chlorosis and drying leaf tips) were observed at initial exposure to the CIP and TTC-spiked wastewater. The growth of plants could be explained by the presence of nutrients $\left(\mathrm{NO}_{3}{ }^{-}-\mathrm{N}\right.$ at $29 \mathrm{mg} / \mathrm{L}$ and $\mathrm{PO}_{4}{ }^{3-}{ }_{-} \mathrm{P}$ at $10.5 \mathrm{mg} / \mathrm{L}$ ). In our previous study, vetiver showed visible physical stress symptoms at a CIP concentration of $10 \mathrm{mg} / \mathrm{L}$ [59], while no significant stress symptoms were seen when vetiver was exposed to an even higher concentration of TTC (75 mg/L) [54]. Higher stress on vetiver was also induced by CIP than TTC in the current study, which may be caused by higher translocation factor for $\mathrm{CIP}$, which induced more CIP accumulation in vetiver shoots. Thus, the experimental removal of TTC was more consistent with the predicted removal. However, vetiver was more sensitive to CIP concentrations and other minor variations in experimental conditions (e.g., temperature and availability of light, $[65,66])$, which induced deviations between experimental and predicted outcomes.

Since the uptake of contaminants can affect the overall health and growth of the plant, which could be indicated by Chl content in plant shoot tissue [61,67], it is implied that the overall health of vetiver grass was not significantly influenced in this study. In comparison, our previous studies have shown that CIP negatively affects the chlorophyll content of vetiver grass [59]. This may be a cumulative effect of CIP-induced stress as it also affected the total protein content of vetiver root and shoot and triggered activation of stress enzymes [59]. Rydzyński et al. (2017) also reported a significant decrease of $\mathrm{Chl}$ in the leaves of Yellow Lupine, especially in new leaves, when exposed to CIP and TTC [68]. CIP and TTC induce chl decay and a decrease in chl concentration. However, in this study, the chl content remained relatively steady, and the biomass of the plants increased by $4 \%$ within 10 days without significant physical stress symptoms. These observations indicate that vetiver grass may tolerate antibiotic stress better when plant density is high when compared to individual plants that were used in our previous report in Panja et al. [59], and Rydzyński et al. [58,68].

The decline in CIP and TTC concentrations in the plant-free control setup may have been caused by adsorption, and bacterial degradation. Golet et al. (2003) reported the removal of antibiotics (e.g., CIP) associated with suspended solids in wastewater [69]. Lou et al. (2018) demonstrated the adsorption of TTC on suspended organic matters in swine wastewater [70]. Thus, with turbidity at 13.4 NTU and electrical conductivity of $801 \mu \mathrm{S} / \mathrm{cm}$ in the wastewater effluent, the loss of CIP and TTC in the plant-free control setup may be induced by adsorption onto solids and then precipitation, which would have been removed by filtration before the antibiotics were quantified. Another possibility is bacterial degradation. Antibiotic-resistant bacteria may exist in the wastewater effluent used for this research [71]. Bacteria in wastewater treatment facilities may also become antibiotic-resistant through horizontal gene transfer [72]. Therefore, the decrease in the antibiotic concentration in the control setup could be attributed to microbial degradation. Since TTC is more widely applied and has been in use much longer than CIP, TTC-resistant bacteria may be more abundant than CIP-resistant bacteria [58,72], leading to more TTC degradation than CIP.

In our study, vetiver was able to remove significant levels of TN and TP. Nitrogen and phosphorous removal from wastewater by phytoremediation have been widely reported. The removal efficiencies by plants are highly dependent on the plant species and the coexisting microorganisms in wastewater. Ojoawo et al. (2015) tested Canna generalis reeds for the removal of nitrate and phosphate in domestic wastewater and found only $52 \%$ and $9 \%$ 
of these two contaminants were removed, respectively [73]. Recently, Nizam et al. (2020) compared five plants (Centella asiatica, Ipomoea aquatica, Salvinia molesta, Eichhornia crassipes, and Pistia stratiotes) for their capacity to remove nitrogen and phosphorous [74]. Although up to $98 \%$ of nitrogen was removed by Centella asiatica and up to $98 \%$ of phosphorous was removed by Eichhornia crassipes, there were significant differences in performance among the five species. In some cases, other contributors (e.g., microorganism degradation and solid adsorption/precipitation) may work more efficiently than plants. As described by Zhang et al. (2007), plants contributed to about $22 \%$ and $33 \%$ for TN and TP removal, respectively, while unplanted control experiments reached over $50 \%$ for both $\mathrm{TN}$ and TP [75]. Song et al. (2011) also reported the important role of microorganisms, along with macrophytes, in removing nutrients from water matrices [76]. In this research, high concentrations $(10 \mathrm{mg} / \mathrm{L})$ of two broad-spectrum antibiotics were spiked in the reactor influent, so the growth of most microorganisms was possibly inhibited in the reactor and vetiver grass contributed significantly to the $\mathrm{TN}$ and $\mathrm{TP}$ consumption, as only $7 \%$ of $\mathrm{TN}$ and $6 \%$ of TP were consumed in the plant free control reactor. The small decline in the control reactor could be due to the adsorption to solids and a small amount of degradation by antibiotic-resistant bacteria. Vetiver grass has been reported to remove nitrogen and phosphorous with high efficiency $[49,57,77]$. It can tolerate high concentrations of nutrients before significant stress symptoms are visible in the plant [49].

The high removal efficiencies for TN and TP observed in this study are consistent with previous studies on nutrient removal from wastewater by vetiver grass [49,57]. Upon reaching the steady-state condition, there were no significant differences in the removal kinetics of TN and TP. Wang and Sample (2014) reported a similar study where pickerelweed (Pontederia cordata L.) and soft stem bulrush (Schoenoplectus tabernaemontani) were used in a floating platform to remove nutrients from a stormwater retention pond [78].

Vetiver removed COD with high efficiency, and a significant difference between the vetiver system and the unplanted control setup was observed. COD removal from wastewater by plants at varying efficiencies is recognized by researchers. By using Salvinia molesta during phytoremediation for palm oil mill effluent, 39\% of COD was removed together with the consumption of nitrogen and phosphorous [79]. In addition to $96 \%$ lead removal at an initial lead concentration of $2 \mathrm{mg} / \mathrm{L}$, over $50 \%$ of COD was reduced by Eichhornia crassipes within 12 days in another study [80]. Mahajan et al. (2019) treated diluted textile effluent by phytoremediation using Chara vulgaris, which showed $78 \%$ of the initial COD at $216 \mathrm{mg} / \mathrm{L}$ was removed [81]. Tambunan et al. (2018) found $81 \%$ of COD can be removed from the original batik wastewater with a high initial COD at $2900 \mathrm{mg} / \mathrm{L}$ by vetiver grass; by using diluted batik wastewater, the COD removal efficiency reached $89 \%$ [67]. This high COD removal capacity by vetiver reported by Tambunan et al. (2018) is consistent with our study.

\section{Conclusions}

Our PFR system showed high efficiency and great promise in treating secondary wastewater effluent. Further investigation is needed to optimize the treatment system on a larger scale. The increase in biomass production in a constructed wetland setup could be an advantage, as the biomass can be periodically harvested to produce compost or bioethanol. In future field-scale experiments, two major parameters could be manipulated to optimize the constructed wetland: (i) the hydraulic retention time, and (ii) the plant density. As constructed wetland is a cost-effective and green technology, it can be used as a retrofit for an existing wastewater treatment plant or act independently to remove traditional and emerging contaminants. The majority of WWTPs in the United States are located in the outskirts of urban settlements or in rural areas where availability of land is not an issue. With minimal establishment cost (only for excavation and plumbing), a gravity-flow vetiver-based constructed wetland can be successfully operated to remove major contaminants from urban wastewater. A vetiver-based constructed wetland can also be installed at minimal cost in rural areas where residents have no access to a wastewater 
treatment plant. In many underdeveloped countries, wastewater is discharged directly to water bodies without any treatment. The same technique can also be applied in sewage canals because they are ideal plug flow reactors. The added benefit of vetiver is that under optimal growth conditions, it exhibits rapid growth. Whereas the harvested vetiver is primarily used for composting, the use of vetiver biomass through novel initiatives such as using vetiver biomass for biogas and bioethanol production could promote sustainability.

Supplementary Materials: The following are available online at https: / www.mdpi.com/article / 10.3390/toxics9040084/s1, Figure S1: Removal of total nitrogen content according to predicted and experimental data from day 7 to 10, Figure S2: Removal of total phosphorus content according to predicted and experimental data from day 7 to 10 .

Author Contributions: Conceptualization, D.S.; Methodology, S.P. and D.S.; Data Curation, S.P.; Writing-Original Draft Preparation, S.P.; Writing—Review and Editing, D.S., Z.Z. and R.D.; Visualization, Z.Z. and R.D.; Supervision, D.S.; Project Administration, D.S.; Funding Acquisition, D.S. All authors have read and agreed to the published version of the manuscript.

Funding: This publication is the result of work sponsored by New Jersey Sea Grant with funds from the National Oceanic and Atmospheric Administration (NOAA) Office of Sea Grant, U.S. Department of Commerce, under NOAA grant \#NA10OAR4170085 and the New Jersey Sea Grant Consortium. The statements, findings, conclusions, and recommendations are those of the author(s) and do not necessarily reflect the views of New Jersey Sea Grant or the U.S. Department of Commerce. NJSG-21-974.

Data Availability Statement: Data presented in this study are available on request from the corresponding author.

Acknowledgments: S.P. thanks the New Jersey Water Resources Research Institute (NJWRRI) and United States Geological Survey (USGS) for providing student research funding for the research. The authors also thank Roger Marques from the Joint Meeting of Essex and Union Counties wastewater treatment plant for granting access to collect wastewater effluent.

Conflicts of Interest: The authors declare no conflict of interest.

\section{References}

1. Rivera-Utrilla, J.; Sánchez-Polo, M.; Ferro-García, M.Á.; Prados-Joya, G.; Ocampo-Pérez, R. Pharmaceuticals as emerging contaminants and their removal from water. A review. Chemosphere 2013, 93, 1268-1287. [CrossRef] [PubMed]

2. Casado, J.; Brigden, K.; Santillo, D.; Johnston, P. Screening of pesticides and veterinary drugs in small streams in the European Union by liquid chromatography high resolution mass spectrometry. Sci. Total Environ. 2019, 670, 1204-1225. [CrossRef] [PubMed]

3. Breton, R.; Boxall, A. Pharmaceuticals and personal care products in the environment: Regulatory drivers and research needs. Qsar Comb. Sci. 2003, 22, 399-409. [CrossRef]

4. Zhang, D.; Gersberg, R.M.; Ng, W.J.; Tan, S.K. Removal of pharmaceuticals and personal care products in aquatic plant-based systems: A review. Environ. Pollut. 2014, 184, 620-639. [CrossRef]

5. Hartley, D.L.; Jones, K.R.; Tobian, J.; LeBlanc, D.J.; Macrina, F. Disseminated tetracycline resistance in oral streptococci: Implication of a conjugative transposon. Infect. Immun. 1984, 45, 13-17. [CrossRef]

6. Chopra, I.; Hawkey, P.; Hinton, M. Tetracyclines, molecular and clinical aspects. J. Antimicrob. Chemother. 1992, $29,245-277$. [CrossRef]

7. Roberts, M. Tetracycline resistance determinants: Mechanisms of action, regulation of expression, genetic mobility, and distribution. FEMS Microbiol. Rev. 1996, 19, 1-24. [CrossRef]

8. Hawker, D.W.; Cropp, R.; Boonsaner, M. Uptake of zwitterionic antibiotics by rice (Oryza sativa L.) in contaminated soil. J. Hazard. Mater. 2013, 263, 458-466. [CrossRef] [PubMed]

9. Pagliara, A.; Carrupt, P.-A.; Caron, G.; Gaillard, P.; Testa, B. Lipophilicity profiles of ampholytes. Chem. Rev. 1997, 97, 3385-3400. [CrossRef]

10. Qiang, Z.; Adams, C. Potentiometric determination of acid dissociation constants (pKa) for human and veterinary antibiotics. Water Res. 2004, 38, 2874-2890. [CrossRef]

11. Ding, S.; Han, C.; Wang, Y.; Yao, L.; Wang, Y.; Xu, D.; Sun, Q.; Williams, P.N.; Zhang, C. In situ, high-resolution imaging of labile phosphorus in sediments of a large eutrophic lake. Water Res. 2015, 74, 100-109. [CrossRef]

12. Schindler, D.W.; Hecky, R.E.; Findlay, D.L.; Stainton, M.P.; Parker, B.R.; Paterson, M.J.; Beaty, K.G.; Lyng, M.; Kasian, S.E.M. Eutrophication of lakes cannot be controlled by reducing nitrogen input: Results of a 37-year whole-ecosystem experiment. Proc. Natl. Acad. Sci. USA 2008, 105, 11254-11258. [CrossRef] [PubMed] 
13. Xin, J.; Liu, Y.; Chen, F.; Duan, Y.; Wei, G.; Zheng, X.; Li, M. The missing nitrogen pieces: A critical review on the distribution, transformation, and budget of nitrogen in the vadose zone-groundwater system. Water Res. 2019, 165, 114977. [CrossRef] [PubMed]

14. Ahn, Y.; Logan, B.E. Effectiveness of domestic wastewater treatment using microbial fuel cells at ambient and mesophilic temperatures. Bioresour. Technol. 2010, 101, 469-475. [CrossRef]

15. Feng, Y.; He, W.; Liu, J.; Wang, X.; Qu, Y.; Ren, N. A horizontal plug flow and stackable pilot microbial fuel cell for municipal wastewater treatment. Bioresour. Technol. 2014, 156, 132-138. [CrossRef]

16. Rabaey, K.; Verstraete, W. Microbial fuel cells: Novel biotechnology for energy generation. TRENDS Biotechnol. 2005, 23, 291-298. [CrossRef] [PubMed]

17. De Witte, B.; Dewulf, J.; Demeestere, K.; Van Langenhove, H. Ozonation and advanced oxidation by the peroxone process of ciprofloxacin in water. J. Hazard. Mater. 2009, 161, 701-708. [CrossRef]

18. Ji, Y.; Ferronato, C.; Salvador, A.; Yang, X.; Chovelon, J.-M. Degradation of ciprofloxacin and sulfamethoxazole by ferrousactivated persulfate: Implications for remediation of groundwater contaminated by antibiotics. Sci. Total Environ. 2014, 472, 800-808. [CrossRef]

19. Vasconcelos, T.G.; Henriques, D.M.; König, A.; Martins, A.F.; Kümmerer, K. Photo-degradation of the antimicrobial ciprofloxacin at high $\mathrm{pH}$ : Identification and biodegradability assessment of the primary by-products. Chemosphere 2009, 76, 487-493. [CrossRef]

20. Fu, H.; Yang, L.; Wan, Y.; Xu, Z.; Zhu, D. Adsorption of pharmaceuticals to microporous activated carbon treated with potassium hydroxide, carbon dioxide, and steam. J. Environ. Qual. 2011, 40, 1886-1894. [CrossRef]

21. Rakshit, S.; Sarkar, D.; Elzinga, E.J.; Punamiya, P.; Datta, R. Mechanisms of ciprofloxacin removal by nano-sized magnetite. J. Hazard. Mater. 2013, 246, 221-226. [CrossRef] [PubMed]

22. Gersberci, R.; Man, G. Role of aquatic plants in wastewater treatment by artificial wetlands. Water Res. 1986. [CrossRef]

23. Kadlec, R.H.; Wallace, S. Treatment Wetlands; CRC Press: Boca Raton, FL, USA, 2008.

24. Eapen, S.; Singh, S.; D'souza, S. Advances in development of transgenic plants for remediation of xenobiotic pollutants. Biotechnol. Adv. 2007, 25, 442-451. [CrossRef]

25. Gan, S.; Lau, E.; Ng, H. Remediation of soils contaminated with polycyclic aromatic hydrocarbons (PAHs). J. Hazard. Mater. 2009, 172, 532-549. [CrossRef] [PubMed]

26. Liu, X.; Zhou, Y.; Zhang, J.; Luo, L.; Yang, Y.; Huang, H.; Peng, H.; Tang, L.; Mu, Y. Insight into electro-Fenton and photo-Fenton for the degradation of antibiotics: Mechanism study and research gaps. Chem. Eng. J. 2018, 347, 379-397. [CrossRef]

27. Zhang, B.; Zheng, J.; Sharp, R. Phytoremediation in engineered wetlands: Mechanisms and applications. Procedia Environ. Sci. 2010, 2, 1315-1325. [CrossRef]

28. Susarla, S.; Medina, V.F.; McCutcheon, S.C. Phytoremediation: An ecological solution to organic chemical contamination. Ecol. Eng. 2002, 18, 647-658. [CrossRef]

29. Haberl, R.; Grego, S.; Langergraber, G.; Kadlec, R.H.; Cicalini, A.-R.; Dias, S.M.; Novais, J.M.; Aubert, S.; Gerth, A.; Thomas, H. Constructed wetlands for the treatment of organic pollutants. J. Soils Sediments 2003, 3, 109. [CrossRef]

30. Imfeld, G.; Braeckevelt, M.; Kuschk, P.; Richnow, H.H. Monitoring and assessing processes of organic chemicals removal in constructed wetlands. Chemosphere 2009, 74, 349-362. [CrossRef]

31. Olette, R.; Couderchet, M.; Biagianti, S.; Eullaffroy, P. Toxicity and removal of pesticides by selected aquatic plants. Chemosphere 2008, 70, 1414-1421. [CrossRef]

32. Vymazal, J.; Kröpfelová, L. Removal of organics in constructed wetlands with horizontal sub-surface flow: A review of the field experience. Sci. Total Environ. 2009, 407, 3911-3922. [CrossRef]

33. Truong, P.N.; Foong, Y.K.; Guthrie, M.; Hung, Y.-T. Phytoremediation of heavy metal contaminated soils and water using vetiver grass. In Environmental Bioengineering; Humana Press: Totowa, NJ, USA, 2010; pp. 233-275.

34. Truong, P.; Van, T.; Pinners, E. Vetiver system for prevention and treatment of contaminated water and land. In The Vetiver System for Improving Water Quality the Prevention and Treatment of Contaminated Water and Land; The Vetiver Network International: San Antonio, TX, USA, 2008; Volume 1, p. 33. Available online: http:/ / www.vetiver.org/TVN_Water_quality\%202\%20ed.pdf (accessed on 10 March 2021).

35. Diyabalanage, S.; Samarakoon, K.; Adikari, S.; Hewawasam, T. Impact of soil and water conservation measures on soil erosion rate and sediment yields in a tropical watershed in the Central Highlands of Sri Lanka. Appl. Geogr. 2017, 79, 103-114. [CrossRef]

36. Donjadee, S.; Tingsanchali, T. Soil and water conservation on steep slopes by mulching using rice straw and vetiver grass clippings. Agric. Nat. Resour. 2016, 50, 75-79. [CrossRef]

37. Chowdhury, M.E.; Hossain, A.; Muktadir, H. Evaluation of the river training work of Padma river through a mathematical approach. J. Mod. Sci. Technol. 2018, 6, 52-62.

38. Tang, V.T.; Fu, D.; Ngoc Binh, T.; Rene, E.R.; Sang, T.T.T.; Singh, R.P. An Investigation on performance and structure of ecological revetment in a sub-tropical area: A case study on cuatien river, vinh city, Vietnam. Water 2018, 10, 636. [CrossRef]

39. Zaman, M.W.; Asik, T.Z.; Rumi, M.Y.; Shahin, H. Geotechnical hazard analysis of river embankment of bangladesh and its protectability. Int. J. 2016, 10, 2050-2057. [CrossRef]

40. Andra, S.S.; Datta, R.; Sarkar, D.; Makris, K.C.; Mullens, C.P.; Sahi, S.V.; Bach, S.B. Induction of lead-binding phytochelatins in vetiver grass [Vetiveria zizanioides (L.)]. J. Environ. Qual. 2009, 38, 868-877. [CrossRef] 
41. Attinti, R.; Barrett, K.R.; Datta, R.; Sarkar, D. Ethylenediaminedisuccinic acid (EDDS) enhances phytoextraction of lead by vetiver grass from contaminated residential soils in a panel study in the field. Environ. Pollut. 2017, 225, 524-533. [CrossRef]

42. Pidatala, V.R.; Li, K.; Sarkar, D.; Ramakrishna, W.; Datta, R. Identification of biochemical pathways associated with lead tolerance and detoxification in Chrysopogon zizanioides L. Nash (Vetiver) by metabolic profiling. Environ. Sci. Technol. 2016, 50, 2530-2537. [CrossRef]

43. Punamiya, P.; Datta, R.; Sarkar, D.; Barber, S.; Patel, M.; Das, P. Symbiotic role of Glomus mosseae in phytoextraction of lead in vetiver grass [Chrysopogon zizanioides (L.)]. J. Hazard. Mater. 2010, 177, 465-474. [CrossRef]

44. Das, P.; Datta, R.; Makris, K.C.; Sarkar, D. Vetiver grass is capable of removing TNT from soil in the presence of urea. Environ. Pollut. 2010, 158, 1980-1983. [CrossRef]

45. RoyChowdhury, A.; Sarkar, D.; Datta, R. Remediation of acid mine drainage-impacted water. Curr. Pollut. Rep. 2015, 1, 131-141. [CrossRef]

46. RoyChowdhury, A.; Datta, R.; Sarkar, D. Heavy Metal Pollution and Remediation. In Green Chemistry; Elsevier: Amsterdam, The Netherlands, 2018; pp. 359-373.

47. Makris, K.C.; Shakya, K.M.; Datta, R.; Sarkar, D.; Pachanoor, D. High uptake of 2, 4, 6-trinitrotoluene by vetiver grass-Potential for phytoremediation? Environ. Pollut. 2007, 146, 1-4. [CrossRef] [PubMed]

48. Das, P.; Sarkar, D.; Makris, K.C.; Datta, R. Urea-facilitated uptake and nitroreductase-mediated transformation of 2, 4, 6trinitrotoluene in soil using vetiver grass. J. Environ. Chem. Eng. 2015, 3, 445-452. [CrossRef]

49. Panja, S.; Sarkar, D.; Datta, R. Vetiver grass (Chrysopogon zizanioides) is capable of removing insensitive high explosives from munition industry wastewater. Chemosphere 2018, 209, 920-927. [CrossRef] [PubMed]

50. RoyChowdhury, A.; Mukherjee, P.; Panja, S.; Datta, R.; Christodoulatos, C.; Sarkar, D. Evidence for Phytoremediation and Phytoexcretion of NTO from Industrial Wastewater by Vetiver Grass. Molecules 2021, 26, 74. [CrossRef]

51. Percy, I.; Truong, P. Landfill leachate disposal with irrigated vetiver grass. In Proceedings of the Third International Conference on Vetiver, Guangzhou, China, 6-9 October 2003.

52. Roongtanakiat, N.; Osotsapar, Y.; Yindiram, C. Effects of soil amendment on growth and heavy metals content in vetiver grown on iron ore tailings. Kasetsart J. 2008, 42, 397-406.

53. Datta, R.; Das, P.; Smith, S.; Punamiya, P.; Ramanathan, D.M.; Reddy, R.; Sarkar, D. Phytoremediation potential of vetiver grass [Chrysopogon zizanioides (L.)] for tetracycline. Int. J. Phytoremed. 2013, 15, 343-351. [CrossRef]

54. Sengupta, A.; Sarkar, D.; Das, P.; Panja, S.; Parikh, C.; Ramanathan, D.; Bagley, S.; Datta, R. Tetracycline uptake and metabolism by vetiver grass (Chrysopogon zizanioides L. Nash). Environ. Sci. Pollut. Res. 2016, 23, 24880-24889. [CrossRef]

55. Panja, S.; Das, P.; Sarkar, D.; Deng, Y.; Datta, R. Potential of vetiver grass to remove oxytetracycline and ciprofloxacin from aquatic media: Preliminary results from a hydroponic study. In Proceedings of the Geological Society of America Abstracts with Program, Vancouver, MD, Canada, 19-22 October 2014.

56. Worku, A.; Tefera, N.; Kloos, H.; Benor, S. Bioremediation of brewery wastewater using hydroponics planted with vetiver grass in Addis Ababa, Ethiopia. Bioresour. Bioprocess. 2018, 5, 39. [CrossRef]

57. Panja, S.; Sarkar, D.; Datta, R. Removal of antibiotics and nutrients by Vetiver grass (Chrysopogon zizanioides) from secondary wastewater effluent. Int. J. Phytoremed. 2020, 22, 764-773. [CrossRef]

58. Panja, S.; Sarkar, D.; Datta, R. Removal of tetracycline and ciprofloxacin from wastewater by vetiver grass (Chrysopogon zizanioides (L.) Roberty) as a function of nutrient concentrations. Environ. Sci. Pollut. Res. 2020, 27, 34951-34965. [CrossRef]

59. Panja, S.; Sarkar, D.; Li, K.; Datta, R. Uptake and transformation of ciprofloxacin by vetiver grass (Chrysopogon zizanioides). Int. Biodeterior. Biodegrad. 2019, 142, 200-210. [CrossRef]

60. Li, Y.; Zhu, G.; Ng, W.J.; Tan, S.K. A review on removing pharmaceutical contaminants from wastewater by constructed wetlands: Design, performance and mechanism. Sci. Total Environ. 2014, 468-469, 908-932. [CrossRef] [PubMed]

61. Liu, L.; Liu, Y.-h.; Liu, C.-x.; Wang, Z.; Dong, J.; Zhu, G.-f.; Huang, X. Potential effect and accumulation of veterinary antibiotics in Phragmites australis under hydroponic conditions. Ecol. Eng. 2013, 53, 138-143. [CrossRef]

62. Arnon, D. Estimation of total chlorophyll. Plant Physiol. 1949, 24, 1-15. [CrossRef] [PubMed]

63. Yan, Y.; Xu, X.; Shi, C.; Yan, W.; Zhang, L.; Wang, G. Ecotoxicological effects and accumulation of ciprofloxacin in Eichhornia crassipes under hydroponic conditions. Environ. Sci. Pollut. Res. 2019, 26, 30348-30355. [CrossRef] [PubMed]

64. Guo, X.; Liu, M.; Zhong, H.; Li, P.; Zhang, C.; Wei, D.; Zhao, T. Responses of the growth and physiological characteristics of Myriophyllum aquaticum to coexisting tetracyclines and copper in constructed wetland microcosms. Environ. Pollut. 2020, 261, 114204. [CrossRef] [PubMed]

65. Yadav, R.; Sharma, P.; Arya, S.L.; Panwar, P. Acacia nilotica-based silvipastoral systems for resource conservation and improved productivity from degraded lands of the Lower Himalayas. Agrofor. Syst. 2014, 88, 851-863. [CrossRef]

66. $\mathrm{Xu}, \mathrm{L}$. Vetiver research and development: A decade experience from China. In Proceedings of the Second International Vetiver Conference, ORDPB, Bangkok, Thailand, 18-22 January 2002; pp. 311-322.

67. Tambunan, J.A.M.; Effendi, H.; Krisanti, M. Phytoremediating batik wastewater using vetiver Chrysopogon zizanioides (L). Polish J. Environ. Stud. 2018, 27, 1281-1288. [CrossRef]

68. Rydzyński, D.; Piotrowicz-Cieślak, A.I.; Grajek, H.; Michalczyk, D.J. Instability of chlorophyll in yellow lupin seedlings grown in soil contaminated with ciprofloxacin and tetracycline. Chemosphere 2017, 184, 62-73. [CrossRef] [PubMed] 
69. Golet, E.M.; Xifra, I.; Siegrist, H.; Alder, A.C.; Giger, W. Environmental exposure assessment of fluoroquinolone antibacterial agents from sewage to soil. Environ. Sci. Technol. 2003, 37, 3243-3249. [CrossRef]

70. Lou, Y.; Ye, Z.-L.; Chen, S.; Ye, X.; Deng, Y.; Zhang, J. Sorption behavior of tetracyclines on suspended organic matters originating from swine wastewater. J. Environ. Sci. 2018, 65, 144-152. [CrossRef]

71. Fatta-Kassinos, D.; Kalavrouziotis, I.K.; Koukoulakis, P.H.; Vasquez, M. The risks associated with wastewater reuse and xenobiotics in the agroecological environment. Sci. Total Environ. 2011, 409, 3555-3563. [CrossRef]

72. Gao, P.; Munir, M.; Xagoraraki, I. Correlation of tetracycline and sulfonamide antibiotics with corresponding resistance genes and resistant bacteria in a conventional municipal wastewater treatment plant. Sci. Total Environ. 2012, 421, 173-183. [CrossRef] [PubMed]

73. Ojoawo, S.O.; Udayakumar, G.; Naik, P. Phytoremediation of phosphorus and nitrogen with Canna $\mathrm{x}$ generalis reeds in domestic wastewater through NMAMIT constructed wetland. Aquat. Procedia 2015, 4, 349-356. [CrossRef]

74. Mohd Nizam, N.U.; Mohd Hanafiah, M.; Mohd Noor, I.; Abd Karim, H.I. Efficiency of five selected aquatic plants in phytoremediation of aquaculture wastewater. Appl. Sci. 2020, 10, 2712. [CrossRef]

75. Zhang, X.-B.; Peng, L.; Yang, Y.-S.; Chen, W.-R. Phytoremediation of urban wastewater by model wetlands with ornamental hydrophytes. J. Environ. Sci. 2007, 19, 902-909. [CrossRef]

76. Song, H.; Li, X.; Wang, X.; Lu, X. Enhancing nitrogen removal performance of vegetated floating-bed by adding Hyriopsiscumingii Lea and an artificial medium. Fresenius Environ. Bull. 2011, 20, 2435-2441.

77. Angassa, K.; Leta, S.; Mulat, W.; Kloos, H.; Meers, E. Effect of hydraulic loading on bioremediation of municipal wastewater using constructed wetland planted with vetiver grass, Addis Ababa, Ethiopia. Nanotechnol. Environ. Eng. 2019, 4, 6. [CrossRef]

78. Wang, C.-Y.; Sample, D.J. Assessment of the nutrient removal effectiveness of floating treatment wetlands applied to urban retention ponds. J. Environ. Manag. 2014, 137, 23-35. [CrossRef] [PubMed]

79. Ng, Y.S.; Chan, D.J.C. Wastewater phytoremediation by Salvinia molesta. J. Water Process. Eng. 2017, 15, 107-115. [CrossRef]

80. Tanjung, R.; Fahruddin, F.; Samawi, M. Phytoremediation relationship of lead (Pb) by Eichhornia crassipes on pH, BOD and COD in groundwater. J. Phys. Conf. Ser. 2019, 022020. [CrossRef]

81. Mahajan, P.; Kaushal, J.; Upmanyu, A.; Bhatti, J. Assessment of phytoremediation potential of Chara vulgaris to treat toxic pollutants of textile effluent. J. Toxicol. 2019, 2019, 1-11. [CrossRef] [PubMed] 